\title{
"Drugs Paradise": Dutch Stereotypes and Substance Regulation in European Collaborations on Drug Policies in the 1970s
}

\author{
Rafaela de Quadros Rigoni' ${ }^{\circledR}$
}

\begin{abstract}
The Dutch approach toward the consumption and trade of drugs has yielded the country a stereotypical image of a too liberal nation. But how did this image develop and to what extent has it influenced Dutch on drug policies? This article goes back to the 1970s to analyze these questions in the context of the first European collaboration around drug policies, with the creation of the Pompidou Group-Cooperation Group to Combat Drug Abuse and Illicit Trafficking in Drugs. The analysis draws on archival data and literature. Results show that the emergence of the Dutch stereotype of a "drugs paradise" was formed well before the shift in the national Opium Act in 1976 and the existence of coffee shops and was closely connected with the different national and international framing of a drug problem in the 1970s. The Dutch approach was seen as contributing to the increased availability of drugs in other European countries, while fighting the supply of drugs remained the dominant solution for the "drug problem" in the Pompidou group. Dutch policy makers perceived stereotypes as a problem and have indeed influenced the Netherlands to take more conciliatory positions regarding drug policies with the intention to protect the national image. This included trying to keep a low profile regarding their liberal cannabis policies and a high profile as a serious drug trade crime fighter. Consequently, despite the image of a drugs paradise, the Dutch political positions around drugs contained elements of both leniency and strict law enforcement.
\end{abstract}

\section{Keywords}

Pompidou Group, Netherlands, drug policy, drug policy history, national stereotypes

\footnotetext{
' Department of History and Art History, Utrecht University, Utrecht, the Netherlands

Received January 17, 2019. Accepted for publication April II, 2019.

Corresponding Author:

Rafaela de Quadros Rigoni, Department of History and Art History, Utrecht University, Utrecht, the Netherlands.

Email: r.dequadrosrigoni@uu.nl
} 
Worldwide and in the European Union (EU), the Netherlands have been seen as leading in adopting and defending a public health approach toward drugs. Dutch drug policy has been praised and glamorized for its tolerant and pragmatic approach — and condemned and demonized for the same reasons (Cohen \& Reinarman, 1999). Over time, the Netherlands have gained a stereotypical image of a (too) liberal country regarding the consumption and the trade of illicit substances. In the scholarly literature, as well, a tendency to portray the Dutch as liberal regarding their drug policies can be found. Pragmatic, liberal, humane are common adjectives describing the Dutch approach toward drugs (de Kort, 1995; van Solinge, 2002).

But how did this image develop? Important, too, is the possible effects of this image: To what extent (if at all) has it influenced Dutch discourses and practices on drug policies? This article goes back to the 1970 s to analyze these questions.

A crucial arena for investigation is the first European collaboration on drug policies, the Pompidou Group, the Cooperation Group to Combat Drug Abuse and Illicit Trafficking in Drugs (forthwith designated as "PG"). A French initiative, this group was the only and most influential European discussion platform regarding drugs in the 1970s. It was formed as a permanent advisory body, composed of law enforcement, public health, and education experts on drugs. Experts met regularly to debate health, prevention, law enforcement, and legislation harmonization regarding drug use and trade in the European Economic Community (EEC). Twice a year, recommendations on the planning of coordinated actions in the field of drug use and trade were discussed and approved at ministerial meetings of the European Council. The advisory function of the PG allowed it to influence drug decision-making indirectly. In 1980, the group became an organ of the Council of Europe, with a partial agreement status. The group still exists today and counts 38 member states among EU and nonEU countries. It lost its unique position in the mid-1980s when other drug-related groups and committees emerged across Europe (Brule, 1983; Pompidou Group, 2017). Now the Pompidou Group's workings during the seminal 1970s has become a largely unknown chapter of European history.

This article, thus, focuses on this decade, when the Netherlands decided to separate the so-called soft drug (cannabis and hashish) markets from the hard drug (heroin, cocaine, etc.) markets, and subsequently recognized the public health advantages of a harm reduction approach. Years later, increasingly liberal drug policies led to the (in)famous Dutch coffee shops. Surprisingly, as this article will point out, the Dutch stereotypes of a too liberal country arrived well ahead of their actual policy shift. At the same time, it shows just how sensitive Dutch policy makers were to the negative reputation from which their country suffered. The article analyzes how these stereotypes emerged in the 1970s and reveals that they have influenced Dutch discourses and practices on drug policies at both national and international level. Internally divided on drug issues, Dutch politicians and policy makers regarded the international reputation of a liberal drug country as a problem and struggled to pursue harm reduction policies while contradicting the European framing and stereotyping.

\section{Framework and Methodology}

To identify discourses and practices on drug policies as well as stereotypical images arising from them, this article combines the concepts of mentalities of governance and imagology with frame analysis. When choosing a policy direction, different perspectives on what is desirable must be negotiated among a variety of actors. In the case of drug policies, some stakeholders may, for instance, consider that a problem exists when people use illicit drugs. They may propose a total ban on drugs as a regulatory solution and may consider law enforcement professionals as the most legitimate actors to implement this ban by forcefully fighting drug trafficking. Other stakeholders may think, instead, that a drug problem arises only when people become dependent on drugs. They may propose abstinencebased treatments run by medical professionals as a legitimate solution, or peer-based education on how to better control drug use, for example. 
The different actors involved in defining regulations for drugs may interpret the need and the forms of those regulations in different ways; that is, they may "frame" drug problems and solutions for them in divergent ways. Frames are "underlying structures of belief, perception, and appreciation" (Schön \& Rein, 1995, p. 23). They shape the way we perceive the world and the way we interpret practices and events, such as illicit drug use or trade, like a problem in need of certain regulatory intervention. Policies, in this sense, also carry within their core a certain frame and are used to shape, explain, and validate the process of regulating behaviors (Colebatch, 2004). How we understand and construct the need for regulating behaviors, and how we organize this regulation, is what Mitchel Dean (2010) coined "mentalities of governance." The concept binds together the idea of "mentalities"- the rationalities behind a certain action - and "governance"- the process of regulating or governing behaviors. To analyze mentalities of governance, Dean proposes to look at four questions: what is considered to be a problem, what solutions are offered for it, who is the target of such governance, and what is the aim of the regulations. The combination of frame analysis with mentalities of governance, thus, allows pointing out and comparing the different forms of drug problem definitions by the actors involved in the PG and in the Netherlands in the 1970s, along with solutions that were offered as legitimate and main targets to focus the efforts. By mapping countries' definitions of a drug problem, their proposed solutions for it, and the behaviors tartgeted for regulation, the analysis unveils frames and rationalities behind governing drugs.

Finally, by defining specific regulations as legitimate, one may also create (stereotypical) images for those who either accept or deviate from the established regulatory frame. The concept of "imagology" has been used to analyze the formation of national stereotypes both by processes of self-imaging and "othering." The concept helps deconstructing and critically analyzing discourses which single out a nation from the rest of humanity as being somehow different or typical (Beller \& Leerssen, 2008). "National stereotypes" are belief systems which associate attitudes and behaviors as being "typical" of members of a country and as representing an imagined "essence" of a nation. A critical analysis of national stereotypes shows that they owe their construction, dissemination, and impact to historical circumstances; they are dynamic and can only be understood in their historical context (Chew, 2006).

This article combines imagology with mentalities of governance and frame analysis to investigate how different framings of drugs can trigger national stereotypes - in this case, negative ones - and how these may influence countries' political positions and practices in the drug field. Our specific focus is on the stereotypical images of the Netherlands arising in the early European debates and their effects on Dutch political discourse and practices.

This study draws on archival data and literature. The data bring to light discussions on drug policies which occurred among country representatives both at the Dutch national level and at the international level in the newly created Pompidou Group. We consulted the Dutch National Archives, the archives for the Dutch Parliament (Staten-Generaal Digitaal), the Nederlandse Staatscourant, the Delpher database, and the online archives of the Pompidou Group of the Council of Europe.

\section{An Invitation to Combat Drugs and Its Controversies}

The framing of a shared drug problem across EEC members started with an invitation from the French president George Pompidou on August 6, 1971. In a letter addressed to the five members of the EECthe Netherlands, West-Germany, Belgium, Luxemburg, and Italy - and the United Kingdom, which was on the verge of becoming a member, Pompidou invited the governments to participate in a joint effort to "combat" drugs. ${ }^{1}$ In his letter, the president framed the addiction to drugs as an urgent problem in Europe, calling for action:

The spectacular development of addiction is very worrying. If the evil appeared to strike the United States, where the president has underlined the need for vigorous action, it is certain that Europe, in its turn, is 
affected by this scourge. The youth, in particular, suffers the attraction of a fashion that is still relatively limited but must lead to increasing use of terrible drugs whose effects are destructive for the personality, when not mortal. There is a danger of incalculable consequences for our society and its future. (Pompidou, 1971, p. 1)

To prevent further damage, he proposed to foster collaboration among EEC countries by creating a permanent advisory body, formed by Law Enforcement, Public Health, and Education experts on "the fight against addiction."

Along with all invited countries, the Dutch government committed itself to combat drugs within the framework of the PG. Some observers, however, were concerned that this commitment was possibly in tension with other, existing projects in which the Dutch were invested. Challenges included possible conflicts and overlapping activities with international bodies already tackling drug policies, such as the Narcotics Commission, the Council of Europe, the regional office of WHO for Europe, as well as Interpol and the International Narcotics Board. Besides, there was the need for financial support and harmonization of regional treaties and legislation. The greatest concern, however, was the uncertain policy effects of Pompidou's proposal (Teijgeler, 1971). By this time, the Dutch government was considering reframing its regulations on cannabis, differentiating it from drugs considered more harmful. National opinions were divided on the matter, but joining a "fight against the drugs scourge," as proposed by the French, seemed to go in the opposite direction than the incipient national drug policy. Dutch parliamentarians who favored a softer cannabis policy feared that an international commitment to the PG could derail the political process that might lead to such changes (Dolman, Haas-Berger, Egas, Stoffelen, \& Vogd, 1971; NRC Handelsblad, 1971; Volkskrant, 1971).

Indeed, in the first meeting of the PG on November 4, 1971, in Paris, the French framed the drug problem rather narrowly. European youth using heroin and cannabis were seen as "victims" of "evil" drug dealers. While the first needed medical treatment for abstinence, the second was the targeted "enemies." The French widely used words like "combat, force, victory, scourge [and] evil" to strengthen their frame of fighting drugs as a solution. Medical elements such as "abstinence, relapse prevention, [and] cure" portrayed a mentality of governance focused on suppressing drug use behavior (French Delegation, 1971).

The French framing of the fight against trafficking had a direct link with the growing international unrest over the "French connection": a scheme of heroin traffic which supplied most of the heroin used in France and the U.S. According to U.S. narcotics experts, from the poppy fields in Turkey to the heroin refineries in Marseille, the opium and morphine base drug routes passed through Italy and Germany, and sometimes Belgium and the Netherlands. The French were under pressure to act to control drug traffic, and a concerted international effort of the countries involved was seen as necessary. In his opening speech of the new collaboration, Mr. Pompidou himself stated that U.S. president Nixon publicly congratulated the French initiative of uniting efforts in a European front against drugs. The first framing of a shared drug problem among EEC countries, thus, represented a quite repressive mentality of governance and related to pressure from the U.S.

Dutch delegates were nonplussed by this initial stance. The Dutch delegation was of an interministerial nature and was formed by representatives from the Ministry of Health and Environmental Protection (J. H. W. Hoogwater, general director of International Affairs and leader of the delegation; Dr. Teigeler, general inspector of Medicines), the Ministry of Justice (L. Oranje, director of the Department of Constitutional and Criminal Law), and the Ministry of Culture, Recreation and Welfare (L. B. van Ommen, director of the Ministry of Juvenile Affairs, Community Development and Sports). Even though the delegation represented different national viewpoints on drug policy, its participants agreed that the French framing put too much emphasis on notions of "fight" and "evil" (van Ommen, 1971a). 


\section{The Drugs Scourge and the Bad Example}

Between 1971 and 1972, the PG was organized in four commissions which oversaw the areas of prevention and education, health, law enforcement, and harmonization of legislation regarding drugs. In these first debates, member states tried to find common ground for the collaboration by framing a (shared) drug problem. In line with the first meeting, the French framed the problem as urgent: Cannabis and heroin use were considered to have reached alarming proportions among youths, and strong actions were needed to cut drug supplies.

Despite the French plea, neither the Dutch nor the other participant countries recognized an urgent drug problem. Although countries did report an increased use of certain drugs or an increased establishment of a drug traffic network, they did not describe their national situation as alarming. Other participants framed drug use as mostly restricted to cannabis, the illicit market as yet very shy, heroin as rarely seen, and drug dependency as practically nonexistent (Pompidou Group, 1971). Presumably, these countries joined the PG to demonstrate their willingness to collaborate with other EEC members and to prevent further problems with drugs.

The group framed the growing cannabis use by youth and the emerging but still small-scale international drug traffic as potentially problematic. Youth protests and youth travel abroad were seen as challenging. While the first was connected to a growing counterculture including cannabis use, the second was framed as responsible for small-scale traffic across borders. Amsterdam, along with Frankfurt and Trier, was at the top of the list of cities where traveling youngsters would buy drugs, sometimes to sell them back home to pay for their trip (Pompidou Group, 1971). Interestingly enough, of these three cities, only Amsterdam kept being mentioned as a problem in subsequent discussions.

There were reasons for this. In the early 1970s, Amsterdam was seen as a place where drugs were freely available. The French connection was being dismantled in 1972, and the drug transportation routes shifted, giving Amsterdam a more prominent place as a transit hub for heroin trafficking. From the Netherlands, heroin went to the U.S. military bases in Germany and to the U.S. (McCoy, 2003). Moreover, the Dutch had already received strong criticism from Swedish police in the late 1960s due to a flow of amphetamine to that country. While in Sweden, amphetamine was framed as a problematic drug and it was regulated through a ban, in the Netherlands, it was seen as a medicine, being a legal product sold in pharmacies. Swedish pressure led the Dutch government to pass an Act in 1968, regulating amphetamine consumption to take place under medical prescription only. As this proved to be insufficient to curb illegal trade to Sweden, ${ }^{2}$ the Dutch government created another specific regulation. The Amphetamine Act (Nederlandse Staatscourant, 1972) became law in 1972 and punished amphetamine trade taking place without a permit with a maximum of 6 years imprisonment (de Kort, 1995).

Since the late 1960s, the Dutch capital Amsterdam was flooded with tourists from Europe and North America who wanted to experience the freedom of using drugs and the counterculture movement for a less competitive and commercial society. Large numbers of people were sleeping in the Dam square and in the Vondelpark, where the use of drugs was tolerated. Cannabis and LSD were commonly used drugs in these places, as well as in youth centers such as Paradiso, Fantasio, and the Melkweg. In these centers, drug use and trade were tolerated and took place alongside music, theater, macrobiotic food, and yoga (Blok, 2008). This counterculture had been growing since the 1960s, and, over time, the Dutch mentality of governing drug use had shifted. ${ }^{3}$ In the early 1970 s, the Dutch solution was to provide care and social support: low-threshold services, peer-led groups, and incentives to youth associations and youth employment. The use of soft drugs at festivals and youth centers was framed as part of a lifestyle (Ministry of Culture, 1972), rather than seen as a social threat.

These national developments prompted the Dutch to take a different position from others. The Dutch delegation defended normalization and low-threshold support as a solution for cannabis use in the PG. Most PG members, however, adopted a different framing. To a certain extent, they agreed with 
the Dutch that a purely criminal approach would not suffice to govern drug use and that drug users also needed care and prevention measures. The meanings of care and prevention, however, were not necessarily shared among participants. Other member countries framed prevention as avoiding drug use and care as providing or enforcing abstinence-oriented treatments.

The Dutch rationality of normalizing cannabis use in the PG, along with the international image of its capital as a place for free experimentation with drugs, led to a national image of a "drugs paradise." The Dutch delegation mentions such image during the first session of the Pompidou Group, while trying to deny its veracity:

The Netherlands, in European opinion, long is considered to occupy the leading position for consumption of toxic substances, with Amsterdam painted as a "drugs paradise." A too lenient and tolerant policy is blamed for this evil. The reality is, however, much different. [...] Our country is not a Mecca for drug users and drug dealers. (Dutch Delegation, 1971, p. 31) ${ }^{4}$

When the delegation of the Netherlands shared the national discussion of possibly separating cannabis from the list of more harmful drugs in the PG, however, other participants reacted swiftly. Mr. J. Nepote, head of Interpol and PG's observer, underlined his disapproval of what he saw as "freeing dangerous evildoers." He affirmed to expect "repression against drug apology," emphasizing his "mistrust against a permissive society" (Nepote, 1971, p. 78). The Netherlands were portrayed as a bad example of drug use and trade having gone out of control. A PG report summarized:

The hypothesis is advanced that the wave of drug addiction may well be only a wave, the highest point of which already reached in the United States of America would now be reached in the Netherlands. (Pompidou Group, 1972b, p. 5)

An image of the Netherlands as (too) tolerant toward drugs, thus, was confirmed in the PG already in these first debates, long before the country's legal policy shifted toward a regulatory drug market separation and segmentation. Being a transit hub for the heroin trade and a source of amphetamine to Sweden had formed the basis for the image of a lenient country that did not do enough to fight drugs. In the Pompidou Group, the stereotype emerged as such and was reinforced by the connection with Dutch discourses and practices around normalization as a way of governing cannabis use, vis-à-vis a framing of cannabis use among youth as a problem by EEC countries.

\section{Nationally Divided, Internationally Isolated}

Although the Dutch delegation defended normalization as a united front in the PG meetings (van Ommen, 1971a), among themselves they framed the issue differently. The Dutch Minister of Health, Dr. Roelof Kruisinga, for instance, responsible for the national drug policy until 1971, was known for his opposition to drug use decriminalization and the differentiation of cannabis as a softer drug. To him, "prolonged use of hashish and cannabis caused physical and hereditary damage, mental dependency and often led to the transition to hard drugs" (Kruisinga, 1971, p. 802). Two expert committees had been established to advise the government. The first one, the Hulsman Committee (Hulsman \& Blok van der Velden, 1971), advised decriminalization, not just for cannabis, but for all drugs because criminalization was regarded as the cause of stigmatization and marginalization of drug users - and this, not necessarily cannabis use, was framed as problematic. A second committee (Baan) had been set up in 1970 by Dr. Kruisinga to provide further advice. Their report, released in 1972, also affirmed that the risk factor of cannabis use was rather low and that subcultures of drug use should be separated. The Baan committee advised decriminalizing the use and possession of cannabis only. Other drugs with a 
higher risk profile should remain criminalized, and judicial punishment of young cannabis users should be considered as a way of governing drug use (Baan, Veraart, \& Middelen, 1972).

These relatively conservative recommendations of the Baan report consisted mainly of compromises between the three ministries involved, which held different positions (de Kort, 1994). The Ministry of Public Health and Sanitation was somewhat divided but mostly agreed with Dr. Kruisinga's hard-line. They believed frequent cannabis use was a problem as it caused an a-smotivational syndrome and would eventually lead to the use of hard drugs. They also pointed out that the commitments from the 1961 convention would not allow for partial or full decriminalization. The Ministry of Foreign Affairs (1972) opposed cannabis decriminalization concerned with the Dutch image abroad:

Possible decriminalisation in the Netherlands may contribute to the fact that abroad is once again believed that the use of drugs in the Netherlands is not undesirable. [...] A unilateral decision by the Dutch government to impose the possession of narcotic drugs outside the criminal law would, in my opinion, lead to international complications. (p. 1)

The Ministry of Justice was more favorable toward decriminalization. They framed the increasing amount of convictions as making their law enforcement work impossible, a proof of the failure of prohibition as a preventive measure. A market separation and segmentation approach as a form of governance could prevent both users' marginalization and access to hard drugs. The Ministry of Culture, Recreation and Welfare was most in favor of the reform and supported the tolerance of drug use and sale in youth centers to keep the situation under control.

The fact that the Dutch, including the relevant ministries, were divided on the issue of drug policies compromised the country's ability to take a firm stance in the PG. The group's initial debates resulted in recommendations to be discussed and ratified in a ministerial meeting of the European Council in October 1972. The recommendations on harmonization of legislation among participant countries were especially problematic for the Netherlands. ${ }^{5}$ As France and other countries took a stricter approach on governing drug trade and possession than the Netherlands, harmonizing legislation could mean the Dutch would have to abandon normalization and switch to stricter solutions. The group's recommendation for interdiction of all propaganda encouraging drug use could also become a politically sensitive issue, but the major problem was a recommendation stating that "the availability of drugs should be restricted to legitimate requirements in the fields of medicine and science." Agreeing with this would be in conflict with an act regulating cannabis consumption for recreational purposes (Ministry of Health, 1972).

To the Dutch delegation, the PG resolutions were framed in an extremely strict manner and, although they had strongly protested, they had not received much support from other countries (van Ommen, 1971b). Of particular concern were potential national consequences if agreements on such hard-line drug regulatory recommendations would reach Dutch media (Oranje, 1971).

By the time the first ministerial meeting approached and a decision on ratifying the PG recommendations had to be made, a new cabinet was still under formation in the Netherlands. A decision on possible national drug policy changes, thus, was still pending. That led the Dutch delegation to join the ministerial meeting with a recommendation for not ratifying the PG's resolutions or aiming for a common policy. They should, instead, stick to exchanging information and defending drug policy as a national matter, to avoid the EEC overruling national drug policies (de Geer, 1972a).

The Dutch delegation negotiated to soften the legislation harmonization recommendations by transforming them into possibilities to be considered. They also tried to remove from the agreement a sentence stating that countries "should consider the policies of other countries when formulating their policies to fight drugs." This mentality of governance was perceived as a direct attack and a sign that the Netherlands were ready to hinder other members' policies. At the end of the Meeting of Ministers, on October 5, 1972, all countries had accepted the PG's recommendations except for the Netherlands. 
L. B. J. van Stuijt (1972) ${ }^{6}$ shared with the national government a summary of the Dutch delegation's feelings:

During the meeting, the Dutch delegation was, from the very first moment, isolated, both in respect to material and institutional aspects. In the corridors, the Netherlands was qualified as a "permissive society." (p. 1)

The feeling of isolation and the image of permissiveness led, a few days later, to the Dutch Ministry of Foreign Affairs asking the Prime Minister to moderate the objections to the PG declarations. His justification was that, as they were only recommendations, they did not directly imply policy changes. Besides, expressing objections would not help the already isolated position of the Netherlands within the EEC (de Geer, 1972b).

This compromise approach had internal consequences. Both within parliament and in the national press, questions arose regarding the readiness of the government to accept the prescriptions of a group with such a hard-line drug policy agenda. Opponents of a prohibitionist approach framed those in the Dutch government as cowards: they were quick to put national values at risk to agree to international demands. An article published in the Haagse Post, a left-wing weekly, criticized the acceptance of the PG recommendations and affirmed that no one in the Netherlands had welcomed this group except Kruisinga. The article gave a special place to the critical views of van Ommen:

I think there is a clear danger that, at a certain moment, we are being led towards specific directions and measures under international pressure, even if we do not want it. (The Haagse Post, 1972)

Dutch left-wing newspapers such as De Volkskrant ${ }^{7}$ and De Waarheid ${ }^{8}$ had already criticized van Stuijt for having accepted joining the PG and for supporting the rather strict French policies and harsh penalties. The Dutch parliamentary commissions of justice, health, culture, and foreign affairs were especially displeased with van Stuijt's plan to extend police and customs powers and his proposal, together with his justice colleague van Agt, to forbid any propaganda which could lead to drug use (De Waarheid, 1972; Volkskrant, 1972).

The other PG and EEC members were no doubt aware of internal Dutch political divisions over the drug legislation issue. The Dutch government's double-minded attitude toward the PG recommendation presented an image of a country in crisis where drugs were freely available and uncontrolled.

\section{Fighting Heroin, Relaxing on Cannabis}

By 1973, Denmark, Ireland, and Sweden had joined the PG. Heroin use and drug-related offenses were on the rise in many big European cities, and the figure of the "heroin junkie" hit the newspapers' headlines spreading a moral panic around the drug. Heroin junkies were framed as the scum of society, people whose drug habits could lead to crimes and further harm to society (Blok, 2008; Weinhauer, 2006). Soon, the new drug problem was framed as a "heroin epidemic," also in the Pompidou Group. Between 1973 and 1975, the group framed solutions on two fronts: fighting heroin addiction and fighting drug trafficking, with an emphasis on the latter. ${ }^{9}$ A specific subcommittee investigated and proposed therapeutic solutions for addiction. The mentality was that, to govern drug use, abstinence should be the primary goal of treatment, and enforced treatment was endorsed. Opioid Substitution Treatment such as the Methadone Maintenance Therapy (MMT) was controversial but was explored as a means to motivate treatment adherence with abstinence as the final goal (Geerlings, 1973). At that time, the Netherlands, together with Ireland and the UK, offered MMT to people dependent on opioids.

Given the Dutch normalization approach and its stereotype of leniency, it could be expected that the delegation would stand out with more liberal ideas when compared to other PG members. That was not 
the case, however, as the Dutch PG delegation framed heroin addiction treatment in a relatively conservative manner in the PG, supporting both abstinence-based and enforced treatment as ways of governing people who used the substance. The question then arises about the representativeness of the Dutch European voice. We already referred to a divided political landscape in the Netherlands. This was also the case with regard to the approach of the heroin problem. A majority supported MMT under strict control only and enforced treatment for homeless addicts. But there were also activist supporters of alternative care, outreach work, and heroin users' freedom. They framed support for controlled and enforced treatment as brutal and deceiving: a way of controlling users and making them conform to nonuser behavior under the label of psychiatric care (Blok, 2008). These opposing liberal voices, however, were not heard in the PG. There, the Dutch delegation took a unified and rather conservative position, and doing so, they believed, would help to modify the stereotypical image of the Netherlands as a permissive society and a drug paradise.

Also, in terms of law enforcement, contrary to their previous discrediting of strict criminal approaches to govern cannabis use, the Dutch supported the PG's hard-line policy recommendations on drug trafficking and framed the recommended collaboration with Interpol as essential for governing drugs (Tweede Kamer, 1975b, p. 13). The PG recommended that each country would have permanent representatives within Interpol to coordinate actions, exchange information, and form a multilingual team of investigators to fight drug trafficking. The PG budget supported the costs (Interpol, 1973b). Interpol (1973a) set up coordinated antidrugs actions at the EEC frontiers to join forces and resources to discourage trafficking. Neither in the PG nor in the Dutch national parliament was there disagreement about the importance of fighting the international drug trade. However, there were a few parliamentarians who raised questions over the presence of foreign police officers in the Netherlands and why the police were still seizing more cannabis than heroin. The Dutch government responded by framing the international law enforcement control strategy and the expansion of the police workforce as imperative in order to fight the heroin trafficking networks more effectively. ${ }^{10}$

There was, nevertheless, still a point of disagreement between the Dutch delegation and the other members of the PG and that was on the issue of normalization. The Dutch framed normalization as a solution to govern cannabis use only. Back in 1970, various national studies had shown that cannabis use occurred mostly in a social setting. The group of users was framed as a lively socially engaged group of youth, even more than nonusers, and they were thought to have higher intellectual abilities and cultural interests when compared to nonusers. Cannabis use was not framed as connected with an underprivileged social and economic status nor were there any indications of an individual or social pathology among users in general; cannabis users, thus, were not yet regarded as "dropouts" (Ministry of Health, 1972; Pompidou Group, 1972a). Heroin users were framed as a totally different ball game. The rapid spread of heroin use from 1972 onward helped to further differentiate and frame cannabis as a less harmful drug. Heroin became framed as an immediate social and public health problem due to its increasing availability on the market and its spread use among Surinamese immigrants and a small part of white unemployed Dutch youth. Surinamese migrants massively entered the Netherlands after the country's independence from Dutch colonial rule in 1975. They were considered easy targets for both working in the drug trade and developing an addiction due to the lack of social support they found in the country regarding jobs, housing, money, community feeling and family bonds. Heroin use was framed as leading to social downfall, marginalization, and the visible presence of users - or junkiesin the streets. In the public mind in the Netherlands, heroin was connected to problematic drug use, vagrancy or homelessness, public nuisance, public health risks, and criminality (Blok, 2008; Korf, 1995). Separated and segmented markets, thus, were perceived as a way of governing substances which could protect "innocent" cannabis users from getting in touch with a harmful context of hard drug "heroin" users and dealers (van de Bunt \& Muller, 2017).

Not surprisingly, cannabis users were of minor importance to the police. Not having to focus on cannabis use and small-scale trade would relieve police work (Tweede Kamer, 1974) and allow for 
prioritizing fighting "hard drugs." A distinction between soft and hard drugs was already occurring in practice during the first half of the 1970s before the Opium Law effectively changed in 1976. Through the expediency principle, ${ }^{11}$ the Dutch legislation made possible to set priorities for investigation and prosecution. Law enforcement was already tolerating the use and sale of soft drugs in larger citiessuch as Amsterdam, The Hague, and Rotterdam - in certain spaces as youth centers. The tolerant policies aimed to keep hard drugs off the scene.

There was growing public support in the Netherlands for more liberal cannabis legislation, ${ }^{12}$ and this was also reflected within the political arena. From 1967 to 1976, traditional Dutch parties lost ground in favor of more progressive ones. The Labour Party had spent some years in opposition, defending more tolerant policies toward cannabis, until, in 1973, they came into power. The cabinet Den Uyl was the most left-wing cabinet in Dutch political history. It was formed by a coalition of left and center-left-wing parties such as D66, PPR, and the Labour party with the Calvinist AntiRevolutionary party and the Catholic People's Party (KVP) and ruled the country until 1977. This new coalition and its framing of cannabis policies was essential in shaping the changes in the Dutch Opium Act. The 1973 government led to a shift in the rationality of governing cannabis within some ministries, notably the Ministry of Health. Kruisinga, the drugs hard-liner, was succeeded as minister by Irene Vorrink, from the Labour Party, who was in support of a harm reduction and legalization approach (Cohen, 1994). ${ }^{13}$ The liberal mentalities for governing drugs of the new cabinet members included legalizing cannabis and regulating it in the same way as alcohol and tobacco and having a state monopoly on soft drugs. National discussions, however, acknowledged that legalizing cannabis could bring enormous international problems. The Minister of Justice Dries van Agt, for instance, was hesitant in openly defending legalization due to fear of foreign pressure (de Kort, 1994, 1995). Based on the Baan and the Hulsman reports' recommendations, Dutch parliament had been discussing whether it would be possible and desirable to change the Single Convention to affirm that nations could be free, if they wished, to have an exceptional regime for cannabis products (Tweede Kamer, 1972). The same question was debated by a working group on drug policy coordination, which discussed possible regulations for the legal circulation of cannabis in the Netherlands (Samson, 1973).

Following this shift in the national political landscape, the Dutch delegation enthusiastically defended normalization as a way to govern cannabis use and defended the possibility of nonproblematic cannabis use in the PG. Dr. E. Dekker (1973), head inspector of the department of mental hygiene, for instance, voiced strong disagreement with the idea of a necessary escalation to abuse and dependency starting from recreational cannabis use. The most controversial framings-those aiming at the legalization and regulation of cannabis trade-were not brought into debate by the delegation in the Pompidou Group. Even with this careful attitude, though, the Dutch views on recreational use alone raised concerns among other PG members. The Swedish observer Jan Ording, for instance, bothered enough to use part of his holidays to send a handwritten letter to Dr. Dekker raising worries. Along the same lines, the Danish delegate and Commissioner of Health, Mr. Knipschildt, shared his concerns that the Dutch ideas did not represent the PG and could not be accepted (Ministry of Health, 1973). Along with other PG participants, these two representatives framed cannabis as a harmful drug which could lead to dependency, social problems, and the use of stronger and more dangerous drugs. A safe or acceptable recreational use of cannabis was out of the question. PG members disagreed even with the possibility of medicinal use of cannabis and proposed to allow its use for scientific purposes only (Pompidou Group, 1973).

The Dutch had attempted a more conciliatory stance, given their conservative position on heroindependency treatment. They felt they were fully engaged in the fight against the drug trade and did not share in the Group more liberal ideas under debate nationally on the possible legalization of cannabis. This, however, did not suffice to get rid of the stereotype of "being too lenient" toward drugs. The Dutch were still seen as outliers in the PG, and the main reason was their liberal ideas on how to govern cannabis use. 


\section{A Question of Supply}

In late November 1973, the external pressure on the Netherlands for applying stricter regulations increased, this time through an event outside the drug policy field. The Dutch government was in a difficult situation due to its position regarding Egyptian and Syrian troops which had attacked Israel on October 6,1973 . The troops attempted to regain the land that had been occupied by Israel since 1967, and the Dutch government sympathized with the Israeli position. Also, within the EEC, the Netherlands were considered more pro-Israel than other member states, so much so that for a while The Hague found itself isolated (de Kort, 1995). Arab nations imposed an oil embargo against the Netherlands on November 22 as a punishment for its pro-Israel stance. The Netherlands played an essential role in the European oil sector, with Rotterdam being the homeport of Shell and a major hub in international oil processing and distribution. An oil embargo would have enormous consequences for the Dutch economy, and all efforts to repair the political and economic damage were considered justifiable.

The Dutch Minister of Foreign Affairs, thus, asked all Dutch ministries and state secretaries to avoid political disagreements with the member states of the EEC:

\footnotetext{
Regarding recent developments in the Middle East, I emphasise the great importance for the Netherlands to have close cooperation with the Member States of the European Community. Under the current circumstances, only unanimous action by the nine Member States will be able to convince Arab countries of lifting reprehensions against the Netherlands which hinder our relations with Western Europe. In this context the Netherlands should, wherever possible, deny the principle of policy-making and avoid, internationally (thinking, for example, about Dutch voting in international conferences), assuming positions not shared by other Member States or causing friction with other Member States. Therefore, I would appreciate it if you do not take any standpoint that places the Netherlands in an isolated position without carefully consulting with my department. (Ministry of Foreign Affairs, 1973, p. 1)
}

The Arab oil boycott rather unexpectedly influenced the Dutch position on drug policies in the PG. The Dutch delegation was prepared to compromise to placate the neighboring countries on which the Dutch depended for their oil supply. In the years following the boycott, the Dutch delegation did everything to prevent heated arguments in the PG meetings. If the new Dutch drug policies were unacceptable to Germany and the UK, they might reconsider their help in supporting oil deliveries to the Netherlands. The Dutch, thus, assumed an even more conciliatory stance and compromised further in adopting the overall strict policies regarding all other drugs. They did so, also, to safeguard their divergent cannabis regulation (Ruigrok \& van der Born, 2004). In the context of international pressure, oil crisis, and national divisions, softening cannabis regulations were being "bought for the price of a more severe criminal law approach in drug trafficking"(Hellema, Wiebes, \& Witte, 2004). The Netherlands' negative national reputation survived the Oil Crisis, however. By 1975, despite strenuous efforts to combat drug trafficking, the Netherlands were framed internationally as an important hub in the illicit drug trade. Heroin and cannabis trafficking were increasing, as did the availability and seizures of these drugs in the country. The $258 \mathrm{~kg}$ of hashish seized in 1970 rose to 9.8 tons in 1976. In the same period, cannabis seizures rose from $16 \mathrm{~kg}$ to $246 \mathrm{~kg}$. Seizures of heroin also skyrocketed: from $50 \mathrm{~g}$ in 1971 to $171 \mathrm{~kg}$ in 1976 (Drugs Unit, 1976). Dutch police acknowledged that the structure of drug trafficking was changing, and that, despite increased seizures, the price of heroin was decreasing while its quality was rising. The number of people addicted to the drug was also quickly growing. This sudden increase led the Dutch to question whether the Netherlands had indeed grown into the European center of drug trafficking (de Kort, 1995). International pressure stimulated government concerns. In its 1974 report, the International Drug Control Board (INCB, 1974) brought the Netherlands into the spotlight, framing drug trafficking in the country as being of a "serious nature," a problem 
which was endangering also neighboring countries and that required "permanent observation." In 1975, the INCB report stated:

This country [The Netherlands] remains the principal center for the illicit supply and distribution of drugs in Western Europe and continues to attract foreign drug abusers. (p. 15)

The reports framing the Dutch as having a prominent role in the illicit market reinforced the national image of a drug paradise.

By March 1976, the German delegation framed the Netherlands as Germany's most important supplier of heroin. Considerable amounts of the cannabis consumed in Germany were also coming from Dutch territory, they said in the PG. The Germans pushed the Dutch to increase their efforts in fighting drug trafficking as a way of governing the problem. Similar pressure came from the Swedish delegation, who pleaded for a higher Dutch police commitment. The publicity around drug debates in the Dutch parliament coincided with reports over significant seizures of amphetamine and heroin in Sweden. The liberal tone of the debates in the Dutch parliament annoyed Swedish authorities. At the same time, the international image of the Netherlands as a drug supplier raised concerns among the Dutch. The Netherlands were being framed as an enemy of the international regulatory machine, and this could have undesirable consequences. Moreover, the Dutch way of governing drugs was increasing the circulation of illegal goods among EEC countries, something that could hinder the aims to reduce barriers to trade in the region.

Dutch parliamentarians reminded that the INCB reports were framing the Netherlands as the main portal for illegal supplies and distribution in Western Europe (van Leijenhorst, 1976, p. 3020). Countries such as the USA and Sweden reminded the Dutch to take more stringent measures in governing drugs, and together with West Germany, France and Belgium expressed concerns about liberal Dutch cannabis policies (Veder-Smit, 1976, p. 3016). At that point, the Dutch delegate Samson (1976a) affirmed: "It seems desirable to pay more attention to the presentation of the Dutch policy abroad" (p. 5). The pressure, however, was not only external. National opponents of a relaxation of cannabis policies framed their criticism based on the international concerns and affirmed that the liberal policy of Minister Irene Vorrink was responsible for the Dutch image of "a Mecca, of trade and use of drugs" (Piket, 1975, p. 538).

The concern about this negative stereotyping, together with the need to secure political support and oil supply and trade, triggered the Dutch to increase their efforts to fight drug trafficking. This was done both in political discourses and in practice. Assuming a conciliatory approach, Ms. Vorrink (1976), for instance, although openly supporting a softer policy on cannabis, voiced support for a government action of "reducing supply through a powerful approach to the trade in hard drugs" (p. 3162). Van Agt, Minister of Justice, framed the Dutch police as regrettably lagging behind regarding fighting the drug trade when compared to other powerful nations (van Agt, 1975, pp. 278-279). By 1975 , he promised to form a special police team to combat drug trafficking. An additional annual contribution of 28,000 Dutch guilders was made to Interpol in 1975 to extend the international team of investigating officers in the EEC area, particularly in the field of the narcotics (Tweede Kamer, 1975c, p. 72). Dutch parliamentarians who were supportive of the new cannabis policy also agreed with the mentality of governance that fighting the international trade was necessary. Labour Party members, for instance, asked for extra man power for the Narcotics Brigade to intensify the fight against the illegal drug trade (Tweede Kamer, 1975a) and affirmed:

Through strict legislation, one can express its aim of preventing this [illegal drug trade] from happening. [...] we will have to fight international trade if we don't want to be blamed for a soft policy on hard drugs. We must keep our credibility. (Haas-Berger, 1976, p. 3075) 
The new cabinet had to negotiate deals and find a middle way among the different framings of the drug problem. They presented the achieved compromise internationally, with strategic care to emphasize the stricter national views while downplaying more liberalizing ones. Showcasing a strong approach to the hard drugs' trade in this period served three purposes for the Dutch: keeping the support (and oil supply) of other European countries, further differentiating heroin from cannabis to create leeway to relax national policies on the latter, and fighting the image of being a major illicit drug supplier.

\section{Fighting Producing Countries or Diverting the Attention}

On June 23, 1976, drug policies in the Netherlands finally changed. The modified Dutch Opium Act distinguished between cannabis products and drugs with unacceptable risks, such as heroin, cocaine, amphetamines, and LSD. Penalties for the trade in hard drugs were sharply increased, while those for cannabis use and traffic were reduced substantially. The possession of small quantities of cannabis remained punishable but was no longer a reason for arrest. Possession of marijuana and hashish in amounts up to $30 \mathrm{~g}$ became a misdemeanor. To the tolerant cannabis policy on the streets, the Public Prosecutor's Office added high-priority official guidelines for the investigation and prosecution of hard drug trafficking, while giving the lowest priority to small possession of cannabis.

The Dutch delegation announced the legal changes in the PG, but, rather than focusing on the relaxation of cannabis regulations, they framed the new policy as bringing an important strengthening of regulations on hard drugs. They reinforced the increased penalties for hard drugs trafficking, and police measures such as an increased number of personnel fighting the drug trade, police training by the U.S. Drug Enforcement Administration, firmer controls on the medical use of amphetamines and derivatives of opium, and the creation of specialized groups to fight drug peddlers (Dutch Delegation, 1976). To counteract the stereotype of a major drug supplier, the Dutch framed themselves as strongly committed to the war on drugs.

In the PG as well, the Netherlands emphasized the importance of fighting heroin trafficking as a way of governing the drug. Moreover, they introduced a new target by assertively pushing for a restrictive regime toward opium-producing countries (Pompidou Group, 1976). In December 1976, the PG delegate Samson from the Dutch Health Ministry suggested to the French Minister of the Interior, Masson, that the true heroin problem lay outside Europe, in certain Asian countries producing and trafficking opium. As a solution, Samson proposed a diplomatic approach. First, expressing the concern of the cooperating countries regarding the illicit traffic of heroin, which was "threatening the public health and welfare interests of [PG] countries." Second, by establishing a mechanism to periodically exchange information with the countries involved (Samson, 1976b, pp. 1 and 2).

The approach bore fruit, and in the following PG meetings, solutions for the heroin supply and production were framed around fighting poppy production in the Middle East and some Asian countries; Pakistan, Afghanistan, Iran, Turkey, and Thailand were explicitly mentioned (Pompidou Group, 1977). The PG recommended addressing "opium-producing countries" to control the trade from their side, partnering with Interpol, customs, and the UN organizations (Dutch Delegation, 1978). On November 21, 1977, the Group approved its "plan to combat heroin use and traffic," which mentality of governance focused on fighting the illicit drug trade in producing countries:

It is generally agreed that several countries in South-East Asia and the Middle East due to lack of resources, poor legislation or insufficient political willpower, are not taking adequate measures against illicit production and traffic in drugs. (Pompidou Group, 1978b, p. 16)

This new framing of the drug problem targeting opium-producing countries brought benefits both to the Netherlands and to the Pompidou Group. To the first party, it helped to divert 
attention from its national cannabis policy and its role in the drug trade. To the second party, it allowed member countries to alleviate regional European differences by having a common enemy outside European borders.

\section{Lack of Punishment}

Despite this reframing, cannabis and deviant Dutch legislation were still targeted in the PG. According to Christian Bonnet, home secretary and French representative of the PG, a major problem was that legislations in a matter of drug-fighting were different:

Traffickers know how to make use of these disparities and set the head of their illicit trade in the place where the lack of restraint seems to them the more apparent. It is to be feared that by eluding this effort of harmonisation, the European cooperation will make no progress. (Pompidou Group, 1978a, p. 6)

The German minister, Werner Maihofer, affirmed that the key solution was the "harmonisation of legislation, the first step of which could not be but a common attitude towards the penalisation of cases concerning cannabis." Legislation harmonization was set to be the main point of debate in the next PG ministerial conference, planned for June 1979, and the comparatively lower penalties in the Netherlands were framed as a problem within the European cooperation. Germany, France, and Italy strongly emphasized their concerns about the lower penalties adopted by the Netherlands. The French raised questions on the consequences of the Dutch reduction of punishments for cannabis users and whether the Netherlands would attract foreign users of these products. The German delegation stated:

The biggest problem is the application of the penalty regulations in the Netherlands. The Dutch are milder in their judgement of cannabis. (Pompidou Group, 1978a, p. 1)

To Interpol as well, the Dutch approach was facilitating organized crime:

There is a general feeling that the smugglers take advantage of the milder sentencing in the Netherlands. (Pompidou Group, 1978a, p. 4)

Some delegations in the PG remained strongly opposed to seeing cannabis as a less dangerous drug. Germany, for instance, declared to have no intentions of moderating penalties and instead wanted to prohibit cannabis in all its forms. France was no different, and Sweden declared full support for international regulations affirming that "society could not tolerate any other use of drugs than medically motivated; any other use was abuse and had to be vigorously combated" (Pompidou Group, 1979, p. 10).

Even those member countries that agreed that cannabis was less harmful than heroin-like the UK, Belgium, and Denmark - were not willing to change a practical distinction into a legal one. Dutch mentalities for governing cannabis were judged as too liberal and as having potential consequences on illicit drugs trade for other countries. ${ }^{14}$ Dutch lower penalties toward drug offenses were framed as creating an unacceptable gap in the EEC, one that could increase drug-related organized crime as well as drug supply in the EEC. During the 1970s, the EEC aimed at deepening the community by working toward institution building and advancing supranational governance. The possibility of a common currency and the harmonization of economic and related social policies were being negotiated (Blair, 2014). The disruptive Dutch policy, in this context, was framed as a threat to the objectives of a successful common market and a thriving European community.

By the end of the 1970s, despite having joined the fight on the drug trade and helped to reframe the drug problem as being outside Europe, the Dutch still kept the image of being too lenient toward drug 
use and trade. The Netherlands were a much more tolerant country toward drugs than any other PG member, a tolerance which was thought to endanger other countries' drug policies and, ultimately, the functioning of the EEC.

\section{When Stereotypes Interfere With Politics}

This article explored the definitions of a drug problem and the stereotypical images attributed to the Netherlands during the 1970s. It did so in the context of the first European collaboration on drug policies with the creation of the Pompidou Group. It combined the concepts of mentalities of governance and imagology with frame analysis to investigate how countries negotiated the regulation of the use and trade of drugs. The concept of frame analysis combined with mentalities of governance provides the lenses to screen the archival material for the questions: what is framed as a drug problem and perceived as being in need for regulation, which solutions are considered valid, and who the target of the regulations is. Allied to these two, the concept of imagology allowed to analyze how certain interpretations of these framings triggered specific stereotypical images of the Dutch and how these images eventually influenced Dutch attitudes toward national and international drug policies. In this sense, the combined framework broadens the application of the concept of imagology beyond a simple narrative of a "national character" to unveil the connections between national stereotypes and political attitudes. Applied to the archival data, the framework allowed to analyze the connections between framing, stereotyping, and political decisions in the drug policy field.

As we have seen, the emergence of Dutch drug stereotypes was closely connected with the different national and international framing of a drug problem in the 1970s. The Dutch have struggled to cope with the European framing and stereotyping of their drug regulatory policies. Dutch policy makers perceived stereotypes as a problem requiring their attention and have indeed influenced the Netherlands to take more conciliatory positions regarding drug policies both at home and in the Pompidou Group with the intention to protect the national image.

The Dutch stereotypical image of a "drugs paradise" already had formed by 1971, well before the shift in the national Opium Act in 1976 and the existence of coffee shops. Since the first meetings of the Pompidou Group, the perceived participation of the Netherlands in the illicit drug trade was framed as a problem and served as the basis for political pressure and stereotyping. The images of being too lenient toward drug use, of being a supplier nation, and of being too soft on crime stemmed from a focus on the role of the Netherlands in the illicit drug trade, this study reveals. Either through being tolerant toward youth cannabis use, being a transit country for illicit drug trafficking, or lacking punishment for cannabis-related offenses, the Dutch approach was seen as contributing to the increased availability of drugs in other EEC countries.

These stereotypical images linked to trade were directly related to the fact that fighting the supply of drugs remained the dominant solution for the PG throughout the 1970s, whether the drug problem was framed as cannabis use by youth, heroin addiction, or opium-producing countries outside the EEC. The focus on the trade was perhaps a way of maneuvering between and reconciling the different interests of its members. Fighting organized crime had the most obvious appeal for international collaboration, and no country seemed to be against curbing the illicit drug trade. Collaboration and trade ties were to be kept among the EEC, and unregulated trade which deviated from common principles could undermine the EEC project.

Throughout these developments, the Netherlands unsuccessfully fought its stereotypes of a "drug paradise" with an emphasis on its efforts to fight the drug trade. The oil boycott by the Arab nations pressed the Netherlands further into a compromise-seeking approach that pushed them from stoutly defending their liberal cannabis policies to acquiring the highly needed support of neighboring countries through a tough stance on hard drugs and the drug trade. Nevertheless, one can wonder if the sequence of events would have been much different without the Oil Crisis. Most concerned with their 
stereotypical image, the Dutch would have probably continued their efforts to improve their image abroad by supporting the fight against drug trafficking. The Netherlands tried to keep a low profile regarding their liberal cannabis policies and a high profile as a serious drug trade crime fighter, further differentiating heroin use from cannabis use but without giving up on a harm-reduction approach. Yet, the Oil Crisis seems to have significantly influenced the Dutch push to move the target of drug regulations to outside the EEC and toward producing countries. Adopted by the Pompidou Group, this shift helped both the Netherlands to assure EEC support and divert attention from their national cannabis policy and their participation in the drug trade, and the PG to ease national differences by having a common enemy outside European borders. Regardless of this intensified fight against drug trafficking, the Netherlands developed into one of the major drug supply hubs in Europe, provoking further stereotyping among their EEC neighbors. In this context, the effective change of the Dutch Opium Law in 1976 with its regulatory separation between the market for soft and hard drugs was only one of the factors increasing international criticism and reinforcing already existing stereotypical images.

Internally divided in their opinions on drug policies, the Dutch struggled to find a place to pursue their policies while contradicting the European stereotyping. The different framings of drug problems at the national level also played out in the divergent and indecisive political positions of the Netherlands at the international level. In addition, the drug paradise stereotype was used by national opponents of a liberal approach to push for stricter policies at the national level. Dutch policy makers needed to negotiate through different framings for the drug problem internally and internationally, and they did so by adopting compromising approaches. Internationally, they presented the achieved compromise in a unified international position, which may have contributed to one-sided stereotypical views of the country. Despite the image of a drugs paradise, the Netherlands' position contained elements of both leniency and strict law enforcement, a position that was attained in no small measure by its efforts to defeat the negative national framing by others while seeking to retain room for emerging national policy.

\section{Acknowledgments}

The author would like to thank "The Imperative of Regulation" project team, the journal's editors, and the two anonymous reviewers for their helpful and constructive comments; their insights greatly contributed to improving the article.

\section{Declaration of Conflicting Interests}

The author(s) declared no potential conflicts of interest with respect to the research, authorship, and/or publication of this article.

\section{Funding}

The author(s) disclosed receipt of the following financial support for the research, authorship, and/or publication of this article: This research was funded by The Netherlands Organisation for Scientific Research (NWO) within the framework of the project "The Imperative of Regulation: local and (trans-)national dynamics of drug regulatory regimes in the Netherlands since the Second World War" (NWO Grant No. 360-52-80).

\section{ORCID iD}

Rafaela de Quadros Rigoni (D) https://orcid.org/0000-0002-8393-4604

\section{Notes}

1. Words in quotation marks come from the archival records consulted. Where they were in languages other than English, they have been translated. The original language is acknowledged in the references. 
2. The methamphetamine dealer Pauksh, for instance, smuggled amphetamine powder from Italy to the south of the Netherlands, where he packed it into capsules and exported to Sweden.

3. The first responses in the 1950s and 1960s were repressive. When recreational drug use by youth became a social phenomenon in the country, a revised Opium Law (1953) turned the possession of cannabis products into a crime: Smokers were jailed, fined, and sent to (ambulatory) drug treatment, along with moral re-education. The tide changed in the late 1960s, when the numbers of hippie tourists in Amsterdam became too large to allow continuing to prosecute young cannabis users. An increasing number of cannabis arrests were dismissed, festivals increasingly tolerated cannabis use, and in many subsidized youth centers, the staff tolerated the sale of cannabis (see Gemma Blok, "Pride and Prejudice. Dutch and German Drug Policy in Historical Comparative Perspective," 2016).

4. This quote leads us to the assumption that the expression "drugs paradise" to designate the Netherlands was first coined by a European country. A search of the Dutch newspaper's database (Delpher) unfortunately did not reveal the terms' origin nor did a search of the archives of the Dutch parliament. The first mention to the term on these databases dates from 1974, thus, after it has been mentioned by the Dutch delegation in the Pompidou Group. The article, published in the NRC Handelsblad, mentioned that young tourists thought that Amsterdam was a "drugs paradise," an image that the governmental touristic-youth commission was working to deconstruct. The commission was distributing folders in several languages to young tourists, informing them that the Netherlands had penalties for drug possession and trade and that police could search individuals. The number of mentions of the Netherlands as a "drugs paradise" in the Dutch media considerably increases between mid-1980s and early 1990s in comparison to the 1970s. A thorough review of newspapers' databases of the different EEC countries is needed to find mentions of the term in other countries in the 1970s. Such a task, however, is beyond the scope of this article.

5. Recommendations on health and prevention focused on information exchange, joint research, and exchange visits to treatment centers in different countries. As they did not imply policy changes, they could easily be ratified by the Dutch. Recommendations on law enforcement were not a political challenge either, since they focused on closer communication through Interpol and fighting small-scale international traffic, activities the Netherlands already pursued.

6. Stuijt was then from the KVP (Catholic People's Party), a Dutch party which fused with Christian-Historical Union and Anti-Revolutionary party in 1980 to form the Christian Democratic Appeal.

7. De Volkskrant (literally “The People's Paper”) was founded in 1919, originally as a Roman Catholic newspaper closely linked to the Catholic People's Party and the Catholic pillar. It became a left-wing newspaper in the 1960s but began softening its stance in 1980. As of today, it remains as a daily newspaper.

8. De Waarheid (literally "The Truth") was the newspaper of the Communist Party of the Netherlands. It originated in 1940 under the German occupation as a resistance paper. In the last decades, it became a more independent left-wing newspaper, being discontinued on April 28, 1990, due to low circulation.

9. Recommendations on prevention and health were limited to the exchange of information, exchange visits, and joint research. No concerted action or consequence for harmonizing legislations arose from these debates.

10. See, for instance, Staten Generaal Digitaal. Eerste Kamer. Zitting 1972-1973 Aanhangsel, VRAGEN van de heren Schwarz (D'66), Brongersma (P.v.d.A.) en Van Wijk (P.S.P.) inzake de handel in heroïne en andere hard drugs. ANTWOORD van de heer van Agt, Minister van Justitie (Maart 30, 1973); Eerste Kamer. Zitting 1972-1973 Aanhangsel. VRAGEN van de heer IJmkers (C.P.N.) m.b.t. het optreden van Amerikaanse agenten van het Bureau of Narcotics and Dangerous Drugs in Amsterdam (April 12, 1973).

11. The expediency principle holds that the public prosecutor has the discretionary power to refrain from prosecuting a criminal offense if this is judged to be in the public interest.

12. For examples, see Staten Generaal Digitaal. Aanhangsel tot het Verslag van de Handelingen der Tweede Kamer. VRAGEN van de heer Van der Spek (P.S.P.) met betrekking tot de problematiek rondom drugs (November 10, 1972); Eerste Kamer. Zitting 1972-1973 Aanhangsel, VRAGEN van de heren Schwarz (D'66), Brongersma (P.v.d.A.) en Van Wijk (P.S.P.) inzake de handel in heroïne en andere hard drugs. ANTWOORD van de heer van Agt, Minister van Justitie. (Maart 30, 1973). 
13. Ms. Vorrink's son, Koos Zwart, was also a known cannabis activist who ran a radio program (Beursberichten) which announced the daily prices of cannabis and hash.

14. By the end of 1979, the PG recommended that the possession and use of cannabis must be discouraged by effective measures and officialized its position against any initiatives which favor the legalization of cannabis. To the Netherlands, this strict position would bring further pressure regarding the developments of their new cannabis policy and the (in)famous coffee shops in the following decade.

\section{References}

\section{Original Sources}

de Geer, J. (1972a, September 27). [Letter to the Prime Minister]. (NL-HaNA, DG CRM 2.27.19, Inv. Nr. 6568). Den Haag, the Netherlands: Nationaal Archief.

de Geer, J. (1972b, October 9). Ministeraad behandeling drugoverleg te Rome [Council of Ministers dealing with drug consultation in Rome - Report on the Council of Ministers' meeting]. (NL-HaNA, DG CRM 2.27.19, Inv. Nr. 6568 I.Z. 10.142). Den Haag, the Netherlands: Nationaal Archief.

De Waarheid. (1972, September 22). Stuijt kan niet naar drugconferentie Pompidou [Stuijt cannot go to the Pompidou drug conference - Clipping from De Waarheid]. (NL-HaNA, DG Volksgezondheid, 2.15.65, Inv. nr 3285). Den Haag, the Netherlands: Nationaal Archief.

Dekker, E. (1973, July 9). [Letter to the Dutch delegation representing the Pompidou Group]. (NL-HaNA, DG Volksgezondheid, 2.15.65, Inv.nr 3285). Den Haag, the Netherlands: Nationaal Archief.

Dolman, Haas-Berger, Egas, Stoffelen, \& Vogd. (1971, September 9). Vraagstuk van Kamerleden. Doc. N. 119731 van Ministerie van Sociale Zaken En Volksgezondheid [Questioning of parlamentarians to the Ministries of Foreing Affairs, Health, Culture and Social Affairs and Justice]. (NL-HaNA, DG Volksgezondheid, 2.15.65, Inv.nr. 3284). Den Haag, the Netherlands: Nationaal Archief.

Drugs Unit. (1976, March 19). Some figures about the number of persons arrested and the quantities seized during the last 7 years [Report from the Central Criminal Information Department]. (NL-HaNA, DG Volksgezondheid, 2.15.65, Inv.nr 3287). Den Haag, the Netherlands: Nationaal Archief.

Dutch Delegation. (1971, December 14). Première Session des Commissions D'Experts Européens en matière de lutte contre la toxicomanie et le trafic des stupéfiants. Compte Rendu de séance. Saint-Could 14 au 17 Décembre 1971 [First Session of the European Commissions of Experts on the fight against drug addiction and drug trafficking. Meeting report. Saint-Could 14 to 17 December 1971 - Official meeting minutes]. (NLHaNA, DG Volksgezondheid, 2.15.65, Inv.nr. 3284). Den Haag, the Netherlands: Nationaal Archief.

Dutch Delegation. (1976, June 15). Single board meeting. March 1976 [Meeting minutes]. (NL-HaNA, DG Volksgezondheid, 2.15.65, Inv.nr 3287). Den Haag, the Netherlands: Nationaal Archief.

Dutch Delegation. (1978, March 20). Korte verslag vergadering deskundigecomissies in het kader van Pompidouoverleg, 13-14 maart 1978, Stockolm [Brief report of the expert committees meeting in the framework of the Pompidou meeting, 13-14 March 1978, Stockolm]. (NL-HaNA, DG Volksgezondheid, 2.15.65, Inv. nr 3287). Den Haag, the Netherlands: Nationaal Archief.

French Delegation. (1971, November 4). Première Réunion des Experts Européens en matière de lutte contre la toxicomanie et le trafic des stupéfiants. Compte Rendu de séance [First Meeting of European Experts on Drug Abuse and Drug Trafficking. Meeting Report]. (NL-HaNA, DG Volksgezondheid, 2.15.65, Inv.nr. 3284). Den Haag, the Netherlands: Nationaal Archief.

Goede raad en vermaning aan jonge toeristen. NRC Handelsblad. Rotterdam, 04-07-1974. Consulted at Delpher on 05-03-2019,Retrieved from https://resolver.kb.nl/resolve?urn=KBNRC01:000032942:mpeg21:a0016.

Geerlings, P. J. (1973, June 5). Verslag van 5 June 1973 [Report of 5 June 1973-Letter to Samson]. (NL-HaNA, DG Volksgezondheid, 2.15.65, Inv.nr 3286). Den Haag, the Netherlands: Nationaal Archief.

The Haagse Post. (1972, December 13). Drugs: "Pompidou weet nu dat Stuyt zijn best doet" [Drugs: "Pompidou now knows that Stuyt is doing his best" - Clipping from The Haagse Post]. (NL-HaNA, DG CRM 2.27.19, Inv. Nr. 6567). Den Haag, the Netherlands: Nationaal Archief. 
Haas-Berger, I. (1976, February 25). Drugbeleid [Drug policy - Pronouncement during chamber's debate]. (Staten Generaal Digitaal. Teede Kamer 25 Februari 1976). Online Archives of the Dutch Parliament. Retrieved from https://www.statengeneraaldigitaal.nl/

International Drug Control Board. (1974). Report of the International Narcotics Control Board for 1974. Geneva. Retrieved from https://www.incb.org/documents/Publications/AnnualReports/AR1974/AR_1974_English.pdf International Drug Control Board. (1975). Report of the International Narcotics Control Board for 1975. Geneva. Retrieved from https://www.incb.org/documents/Publications/AnnualReports/AR1975/AR_1975_English.pdf Interpol. (1973a, July 18). Sepat plan, operation “Narcontrol 1973.” Interpol N. 3625/stupe/1440/sepat [Report]. (NL-HaNA, DG Volksgezondheid, 2.15.65, Inv.nr 3285). Den Haag, the Netherlands: Nationaal Archief.

Interpol. (1973b, August 2). Evolution du plan SEPAt-Reinforcement de la cooperation contre le traffic illicite des stupefiants. Telex Interpol 27.268 [Evolution of the SEPAt-Reinforcement of cooperation against the illicit traffic in narcotic drugs. Telex Interpol 27.268 - Teleprinter exchange with the Dutch Ministry of Health]. (NLHaNA, DG Volksgezondheid, 2.15.65, Inv.nr 3285). Den Haag, the Netherlands: Nationaal Archief.

Kruisinga, R. (1971, March 3). Eesrte Kamer, 26ste vergadering [First Chamber, 26th meeting - Pronouncement during debate]. (Staten Generaal Digitaal, Eesrte Kamer, 26ste vergadering). Online Archives of the Dutch Parliament. Retrieved from https://www.statengeneraaldigitaal.nl/

Ministry of Culture. (1972). Ludieke manifestaties [Entertainement events - Report from the Ministry of Culture]. (NL-HaNA, DG CRM, 2.27.19, Inv. Nr. 6566). Den Haag, the Netherlands: Nationaal Archief.

Ministry of Foreign Affairs. (1972, May 25). DAZ-106316 [Letter to the Prime Minister and other Ministries]. (NL-HaNA, DG Volksgezondheid, 2.15.65, Inv.nr. 3284). Den Haag, the Netherlands: Nationaal Archief.

Ministry of Foreign Affairs. (1973, November 22). Europese samenwerking. AP-259993 [European cooperation. AP-259993 - Letter to all Ministries and State Secretaries]. (NL-HaNA, DG Volksgezondheid, 2.15.65, Inv.nr 3285). Den Haag, the Netherlands: Nationaal Archief.

Ministry of Health. (1972, September 21). BSG 21.064. Ontwerp Resolutie [BSG 21,064. Draft Resolution - Letter to the Prime Minister with a report]. (NL-HaNA, DG CRM 2.27.19, Inv. Nr. 6567). Den Haag, the Netherlands: Nationaal Archief.

Ministry of Health. (1973, July 10-13). [Collection of letters from Jan Ording and Mr. Knipschildt to Dr. Dekker,]. (NL-HaNA, DG Volksgezondheid, 2.15.65, Inv.nr 3285). Den Haag, the Netherlands: Nationaal Archief.

Nederlandse Staatscourant. (1972, June 12). In- en uitvoerbeschikking amfetaminen 1972 [Decision on import and export of Amphetamines 1972 - Official publication of Dutch Act on amfetamine]. (Nederlandse Staatscourant. Maandag 19 Juni 1972. Nr. 116., p. 3). Den Haag, the Netherlands: National Library Archives.

Nepote, J. (1971, December 16). Première Session des Comissions D'Experts Européens en matière de lutte contre la toxicomanie et le trafic des stupéfiants. Compte Rendu de séance. Saint-Could 14 au 17 Décembre 1971 [First Session of the European Expert Committees on Drug Abuse and Drug Trafficking. Meeting report. Saint-Could 14 to 17 December 1971]. (NL-HaNA, DG Volksgezondheid, 2.15.65, Inv.nr. 3284). Den Haag, the Netherlands: Nationaal Archief.

NRC Handelsblad. (1971, September 13). Vijf Kamerleden tegen te snelle beslissing inzake drugbestrijding [Five MPs against a too quick decision on drug control - Clipping from the NRC Handelsblad]. (HaNA, DG Volksgezondheid, 2.15.65, Inv.nr. 3284). Den Haag, the Netherlands: Nationaal Archief.

Oranje, L. (1971, December 20). [Letter from Oranje to the Secretary General]. (NL-HaNA, DG Volksgezondheid, 2.15.65, Inv.nr. 3284). Den Haag, the Netherlands: Nationaal Archief.

Piket, F. H. (1975, April 8). Handelingen Eerste Kamer 1974-1975 08 april 1975 [Acts Senate 1974-1975 April 8 , 1975 - Pronouncement of Mr. Piket, from the CHU (Christelijk-Historische Unie)]. (Staten Generaal Digitaal. Eerste Kamer 1974-1975). Online Archives of the Dutch Parliament. Retrieved from https://www.statengener aaldigitaal.nl/

Pompidou, G. (1971, August 6). [Letter to Prime Minister of the Netherlands]. (NL-HaNA, DG Volksgezondheid, 2.15.65, Inv.nr. 3284). Den Haag, the Netherlands: Nationaal Archief.

Pompidou Group. (1971, December 17). Première Session des Comissions D'Experts Européens en matière de lutte contre la toxicomanie et le trafic des stupéfiants. Saint-Could 14 au 17 Décembre 1971. Compte Rendu de 
séance [First Session of the European Expert Committees on Drug Abuse and Drug Trafficking. Saint-Could 14 to 17 December 1971. Meeting report]. (NL-HaNA, DG Volksgezondheid, 2.15.65, Inv.nr. 3284). Den Haag, the Netherlands: Nationaal Archief.

Pompidou Group. (1972a, January 31). Comissions des Experts Européens en matière de lutte contre la toxicomanie et le trafic des stupéfiants-31 Janvier 1972 [Official meeting minutes]. (NL-HaNA, DG Volksgezondheid, 2.15.65, Inv.nr 3284). Den Haag, the Netherlands: Nationaal Archief.

Pompidou Group. (1972b, February 6). Comissions des Experts Européens en matière de lutte contre la toxicomanie et le trafic des stupéfiants. Sous-Commission de l'action educative et de linformation [Committees of European Experts on Drug Abuse and Drug Trafficking-31 January 1972]. (NL-HaNA, DG Volksgezondheid, 2.15.65, Inv.nr. 3284). Den Haag, the Netherlands: Nationaal Archief.

Pompidou Group. (1973, March 1). Pompidou overleg. Vergadering van 26 februari tot 1 maart 1973 [Pompidou consultation. Meeting from 26 February to 1 March 1973] (NL-HaNA, DG Volksgezondheid, 2.15.65, Inv.nr. 3286). Den Haag, the Netherlands: Nationaal Archief.

Pompidou Group. (1976, December 1). Poursuite travaux. Commission de Coordination [Working group. Coordination Commission]. (NL-HaNA, DG Volksgezondheid, 2.15.65, Inv.nr. 3287). Den Haag, the Netherlands: Nationaal Archief.

Pompidou Group. (1977, April 12). Vergadering coordinatie commissie, Pompidou overleg [Meeting coordination committee, Pompidou meeting]. (NA. 2.15.65 DG Volksgezondheid. 3287). Den Haag, the Netherlands: Nationaal Archief.

Pompidou Group. (1978a, February 10). 3rd Ministerial Conference Proceedings. 10 February 1978 [Official meeting minutes. Pronouncement of the German Delegation]. (NA. 2.15.65 DG Volksgezondheid. 3288). Den Haag, the Netherlands: Nationaal Archief.

Pompidou Group. (1978b, May 19). First meeting of the committee of experts on legislation and regulation [Official meeting minutes]. (NA. 2.15.65 DG Volksgezondheid. 3288). Den Haag, the Netherlands: Nationaal Archief.

Pompidou Group. (1979, April 29). Minutes of Meeting of experts from the Pompidou Group. 24-25 April 1979 [Official meeting minutes]. (NA. 2.15.65 DG Volksgezondheid. 3289). Den Haag, the Netherlands: Nationaal Archief.

Pompidou Group. (2017). Pompidou Group of the Council of Europe. Online archives of the Pompidou Group. Retrieved February 23, 2017, from http://www.coe.int/T/DG3/Pompidou/default_en.asp

Ruigrok, P., \& van der Born, K. (2004). Hash. Andere Tijden. Netherlands: VPRO. Retrieved from https://www. anderetijden.nl/programma/1/Andere-Tijden/aflevering/477/Hasj

Samson, R. J. (1973, May 8). ARP Rapport: “Touwtrekken om hennep.” Werkgroep coordinatie drugsbeleid [RP Report: "Tug of war around hemp.” Workgroup coordination drug policy]. (NL-HaNA, DG Volksgezondheid, 2.15.65, Inv.nr 3286). Den Haag, the Netherlands: Nationaal Archief.

Samson, R. J. (1976a, March 19). Interdepartamentale Stuurgoroep Drugsbeleid. Bijeenkomst coordinatie commissie Pompidou-overleg. dd 11.3.1976 [Interdepartmental Steering Group on Drug Policy. Meeting coordination committee Pompidou consultation. dated 11.3.1976]. (NL-HaNA, DG Volksgezondheid, 2.15.65, Inv. nr 3287). Den Haag, the Netherlands: Nationaal Archief.

Samson, R. J. (1976b, December 1). HGB 128.555 [Personal and confidential letter to Masson]. (NL-HaNA, DG Volksgezondheid, 2.15.65, Inv.nr 3287). Den Haag, the Netherlands: Nationaal Archief.

Teijgeler, C. A. (1971, August 31). Doc N. HI 8014 RS/GL [Letter to the Secretary-General of the Dutch Health Ministry]. (NL-HaNA, DG Volksgezondheid, 2.15.65, Inv.nr. 3284). Den Haag, the Netherlands: Nationaal Archief.

Tweede Kamer. (1972, July 4). Achtergronden en risico's van druggebruik. Kamerstuknummer 11742 ondernummer 2 [Backgrounds and risks of drug use. Chamber number 11742, under number 2 - Chamber debate]. (Staten Generaal Digitaal. Tweede Kamer 1971-1972). Online Archives of the Dutch Parliament. Retrieved from https://www.statengeneraaldigitaal.nl/

Tweede Kamer. (1974). kamerstuknummer 11742 ondernummer 6. Achtergronden en risico's van druggebruik [Chamber number 11742 order number 6. Backgrounds and risks of drug use - Chamber debate]. (Staten 
Generaal Digitaal. Kamerstuk Tweede Kamer 1973-1974 Maart En April 1974). Online Archives of the Dutch Parliament. Retrieved from https://www.statengeneraaldigitaal.nl/

Tweede Kamer. (1975a, April 22). Beleidsdebat Binnenlandse Zaken [Internal Affairs policy debate - Chamber debate]. (Staten Generaal Digitaal. Eerste Kamer 22 April 1975). Online Archives of the Dutch Parliament. Retrieved from https://www.statengeneraaldigitaal.nl/

Tweede Kamer. (1975b, October 1). kamerstuknummer 10124 ondernummer 7. Herziening Politiewet [Parliamentary document number 10124, under number 7. Revision of the Police Act] (Staten Generaal Digitaal. Kamerstuk Tweede Kamer 1975-1976). Online Archives of the Dutch Parliament. Retrieved from https:// www.statengeneraaldigitaal.nl/

Tweede Kamer. (1975c, December). Rijksbegroting voor het dienstjaar 1975. Hoofdstuk VI, Nr. 2 [State budget for the 1975 service year. Chapter VI, Nr. 2] (Staten Generaal Digitaal. Tweede Kamer, Zitting 1974-'75). Online Archives of the Dutch Parliament. Retrieved from https://www.statengeneraaldigitaal.nl/

van Agt, D. (1975, April 23). Beleidsdebat Binnenlandse Zaken [Internal Affairs policy debate - Pronouncement during Chamber debate]. (Staten Generaal Digitaal. Eerste Kamer 23 April 1975). Online Archives of the Dutch Parliament. Retrieved from https://www.statengeneraaldigitaal.nl/

van Leijenhorst, G. (1976, February 26). Handelingen Tweede Kamer 1975-1976 25 februari 1976. Drugbeleid. [Acts Lower House 1975-1976 February 25, 1976. Drug policy].Pronouncement during Chamber debate]. (Staten Generaal Digitaal. Tweede Kamer 1975-1976). Online Archives of the Dutch Parliament. Retrieved from https://www.statengeneraaldigitaal.nl/

van Ommen, L. B. (1971a, November 5). Versla van de Eerste Conferentie [Report of the First Conference - Nota with Conference summary to the Ministry of Health]. (NL-HaNA, DG Volksgezondheid, 2.15.65, Inv.nr. 3284). Den Haag, the Netherlands: Nationaal Archief.

van Ommen, L. B. (1971b, December 24). Korte verslag tweede bijeenkomst "Experts Européens en matière de lutte contre la toxicomanie et le trafic des stupéfiants." Paris 14-17 décembre 1971 [Short report second meeting - "European experts in the fight against drug addiction and drug trafficking." Paris 14-17 December 1971. Letter with short summary of meeting to state secretary Vonhoff]. (NL-HaNA, CRM 2.27.19, Inv. Nr. 6567). Den Haag, the Netherlands: Nationaal Archief.

van Stuijt, L. B. J. (1972, October 5). [Confidential letter to Prime Minister]. (NL-HaNA, DG CRM 2.27.19, Inv. Nr. 6568). Den Haag, the Netherlands: Nationaal Archief.

Veder-Smit, E. (1976, February 25). Tweede Kamer 25 februari 1976. Drugbeleid [Lower House 25 February 1976. Drug policy - Pronouncement during debate]. (Staten Generaal Digitaal. Tweede Kamer 1975-1976). Online Archives of the Dutch Parliament. Retrieved from https://www.statengeneraaldigitaal.nl/

Volkskrant. (1971, September 14). Vragen van PvdA leden: Kamer wenst stem bij drugs-afspraken [Questions from PvdA members: Chamber wants a vote in drug-related appointments - Clipping from Volkskrant, p. 3]. (NL-HaNA, DG Volksgezondheid, 2.15.65, Inv.nr. 3284). Den Haag, the Netherlands: Nationaal Archief.

Volkskrant. (1972, September 21). Kamer vil drugoverleg zonder Nederland [Chamber wants drug consultation without the Netherlands - Clipping from Volkskrant, p. 1]. (NL-HaNA, DG Volksgezondheid, 2.15.65, Inv.nr. 3284). Den Haag, the Netherlands: Nationaal Archief.

Vorrink, I. (1976, March 3). Drugbeleid. Nota Achtergronden en risico's van druggebruik (11 742); wetsontwerp Wijziging van de Opiumwet en enige daarmee verband houdende bepalingen in andere wetten (13407) [Drug policy. Note Backgrounds and risks of drug use (11 742); Bill to amend the Opium Act and any related provisions in other laws (13407) - Pronouncement during chamber debate]. (Staten Generaal Digitaal. Tweede Kamer 3 Maart 1976). Online Archives of the Dutch Parliament. Retrieved from https://www.statengeneraal digitaal.nl/

\section{Secondary Literature}

Baan, P. A. H., Veraart, J. B. M., \& Middelen, W. V. (1972). Achtergronden en risico's van druggebruik: Rapport van de Werkgroep Verdovende Middelen [Backgrounds and risks of drug use: Report of the Working Group on Narcotic Drugs]. 's-Gravenhage, the Netherlands: Staatsuitgeverij. 
Beller, M., \& Leerssen, J. T. (2008). Imagology: The cultural construction and literary representation of national characters: A critical survey. Amsterdam, the Netherlands: Rodopi.

Blair, A. (2014). The European Union since 1945 (2nd ed.). London, England: Taylor \& Francis.

Blok, G. (2008). Pampering "needle freaks" or caring for chronic addicts? Early debates on harm reduction in Amsterdam, 1972-1982. The Social History of Alcohol and Drugs, 22, 243-261.

Blok, G. (2016) Pride and Prejudice. Dutch and German Drug Policy in Historical Comparative Perspective. In: A. Mc Shane (Ed.), Event Report: Intoxication and Politics. London, England. Retrieved from: https://www.dhi. ac.uk/blogs/intoxicantsproject/wp-content/uploads/sites/13/2017/05/5-Blok-Pride-prejudice.pdf

Brule, C. (1983). The role of the Pompidou Group of the Council of Europe in combating drug abuse and illicit drug trafficking. Bulletin on Narcotics, 35, 73-77. Retrieved from https://www.unodc.org/unodc/en/data-andanalysis/bulletin/bulletin_1983-01-01_4_page010.html

Chew, W. L. (2006). What's in a national stereotype? An introduction to imagology at the threshold of the 21 st century. Language and Intercultural Communication, 6, 179-187. doi:10.2167/laic246.0

Cohen, P. (1994). The case of the two Dutch drug policy commissions. An exercise in harm reduction 1968-1976. In 5th International Conference on the Reduction of Drug related Harm, 7-11 March 1994. Toronto, Canada: Addiction Research Foundation. Retrieved from https://pure.uva.nl/ws/files/971668/2218_cohen.case.html

Cohen, P., \& Reinarman, C. (1999). Is Dutch drug policy the Devil? Retrieved from http://www.cedro-uva.org/lib/ reinarman.devil.html

Colebatch, H. K. (2004). Policy. Maidenhead, UK.: Open University Press.

de Kort, M. (1994). The Dutch Cannabis Debate, 1968-1976. Journal of Drug Issues, 24, 417-427. doi:10.1177/ 002204269402400304

de Kort, M. (1995). Tussen patiënt en delinquent: Geschiedenis van het Nederlandse drugsbeleid [Between patient and criminal: History of Dutch drug policy]. Rotterdam, the Netherlands: Erasmus University Rotterdam.

Dean, M. (2010). Governmentality: Power and rule in modern society. Thousand Oaks, CA: Sage.

Hellema, D., Wiebes, C., \& Witte, G. T. (2004). The Netherlands and the oil crisis: Business as usual. Amsterdam, the Netherlands: Amsterdam University Press. Retrieved from https://www.jstor.org/stable/j.ctt46mzm8

Hulsman, L. H. C., \& Blok van der Vlden, W. (1971). Ruimte in het drugbeleid: Rapport [Space in the drug policy: Report]. Meppel, the Netherlands: Boom.

Korf, D. J. (1995). Dutch Treat: Formal control and illicit drug use in the Netherlands. Amsterdam, the Netherlands: Thesis.

McCoy, A. W. (2003). The politics of heroin CIA complicity in the global drug trade; Afghanistan, Southeast Asia, Central America, Colombia. Chicago, IL: Lawrence Hill Books.

Schön, D., \& Rein, M. (1995). Frame reflection: Toward the resolution of intractable policy controversies. New York, NY: Basic books.

van de Bunt, H., \& Muller, T. (2017). The bankruptcy of the Dutch cannabis policy: Time for a restart. In H. Nelen \& D. Siegel (Eds.), Contemporary organized crime: Developments, challenges and responses (Vol. 16, pp. 11-24). Springer International. doi:10.1007/978-3-319-55973-5

van Solinge, T. B. (2002). Drugs and decision-making in the European Union. Amsterdam, the Netherlands: CEDRO, University of Amsterdam.

Weinhauer, K. (2006). Drug consumption in London and Western Berlin during the 1960s and 1970s: Local and transnational perspectives. The Social History of Alcohol and Drugs, 20, 187-224.

\section{Author Biography}

Rafaela de Quadros Rigoni is a postdoctoral researcher studying the history of Dutch drug policy. She holds a $\mathrm{PhD}$ in development studies, and her academic research focuses on comparative drug policy and drug policy implementation. As a consultant, she has carried out research on harm reduction practices in Brazil, South Africa, Indonesia, and the Netherlands. 